\title{
Yakutia as One of the Richest in Natural Resources Regions of the Russian Federation
}

\author{
Victor Marshintsev ${ }^{1}$, Vitaly Gadiyatov ${ }^{2}$ \\ ${ }^{1}$ Department of Earth Sciences, Academy of Sciences of the Republic of Sakha (Yakutia), Yakusk, Russian Federation \\ ${ }^{2}$ Faculty of Civil Engineering, Voronezh State Technical University, Voronezh, Russian Federation
}

\section{Email address:}

mvk2005@mail.ru(V. Marshintsev),gadiatovvg@mail.ru (V. Gadiyatov)

\section{To cite this article:}

Victor Marshintsev, Vitaly Gadiyatov. Yakutia as One of the Richest in Natural Resources Regions of the Russian Federation. Earth Sciences. Vol. 10, No. 3, 2021, pp. 90-94. doi: 10.11648/j.earth.20211003.13

Received: May 5, 2021; Accepted: May 26, 2021; Published: June 3, 2021

\begin{abstract}
The paper presents the analysis of the territory study on the presence of minerals in Yakutia. The purpose of this analysis was to summarize the data on the main deposits located in different geographic regions of the republic. The article provides a scientific review of the current state of the mineral resource base of Yakutia, including general information about the region, geological structure, and the largest mineral deposits. In addition, statistical data on the number of deposits and their reserves are given. The problem of the natural resources usage, as well as the subsoil distribution and rent income, is touched upon. The Republic of Sakha (Yakutia) is one of the largest regions of the Russian Federation, more than half of which is located beyond the Arctic Circle. Despite the harsh climate, significant reserves of various minerals are concentrated in Yakutia. There are large reserves of oil, natural gas, coal, diamonds, gold, silver, tin, niobium, uranium ore and other mineral resources. A number of deposits are unique and large. They include Chayandinskoye oil and gas condensate field, Deputatskoye and Terekhtyakhskoye tin-bearing deposits, Agylkinskoye tungsten deposit, Nezhdaninskoye gold ore deposit, Sarylakhskoye and Sentachanskoye goldantimony deposits and other deposits of silver, rare metals, uranium and other minerals. Of the 35 explored hydrocarbon deposits, 15 are oil and gas condensates, 11 are gas condensates, 2 are oil and gas deposits, and 7 are gas ones. Explored reserves of diamonds in the Yakutian diamondiferous province account for $73.5 \%$ (150 deposits) of the Russian Federation reserves, gold $12.3 \%$ (815 deposits). Mining forms about half of the gross regional product of Yakutia. At the same time the republic ranks $7^{\text {th }}$ in the country, while the life quality of the local population takes about $70^{\text {th }}$ place.
\end{abstract}

Keywords: Deposits, Minerals, Mineral Resource Base, Reserves

\section{Introduction}

The purpose of our research was to analyze the level of knowledge about the mineral resources in Yakutia summarizing the materials on the current state of the mineral resource base and compiling a scientific review.

Information about the geological structure of mineral deposits and the modern mineral resource base of the Republic of Sakha (Yakutia) is included in the monograph of V. K. Marshintsev and V. G. Gadiyatov "Riches of the Yakut Subsoil. Mineral Reserves, Mineral Resource Base", published in the publishing house of VSU [1]. The book considers almost all the minerals discovered in the territory of Yakutia. Among them are combustible minerals, ferrous, precious and non-ferrous metals, mining and chemical raw materials, construction materials, underground water, therapeutic mud, colored stones. For most minerals, reserves or resources are given. In addition, for some types of mineral raw materials, the volume of world production is given. This paper provides an overview of the mineral resource base of Yakutia based on the materials of this monograph, supported by data on reserves or resources.

The Republic of Sakha (Yakutia) is one of the largest and richest regions of the Russian Federation (RF), more than $50 \%$ of which is located beyond the Arctic Circle. Due to this and, in particular, the extremely harsh climate, there has been an increased interest in Yakutia in recent years.

The Cold Pole of the northern hemisphere is located in Yakutia. For the first time, the minimum temperature of minus $67.8{ }^{\circ} \mathrm{C}$ was recorded at the meteorological station in Verkhoyansk on January 15,1885 . Since then, this place has been officially recognized as the Cold Pole [2]. The exiled 
Ivan Khudyakov began collecting regular information about the weather in 1869 . On his own initiative, he carried out the necessary measurements for two years and proved that Verkhoyansk is the coldest place in the northern hemisphere. Later, a permanent meteorological station was established in Verkhoyansk, which was included in the system of the international climate network.

In 1924 geologist S. V. Obruchev, who later became a corresponding member of the USSR Academy of Sciences, during an expedition to the Chersky Ridge, wrote in his field diary that in the village of Tomtor in the Oymyakon district, the air temperature was $-71.2^{\circ} \mathrm{C}$. However, there is no documentary evidence of the authenticity of its measurements, so they are not officially recognized. 9 years later in February 1933 the meteorological station at Oymyakon Airport (Tomtor village) recorded a temperature of $-67.7^{\circ} \mathrm{C}$. That is only $0.1^{\circ} \mathrm{C}$ lower than in Verkhoyansk. But for now, the official status of the North Pole of Cold still belongs to Verkhoyansk. Even if Verkhoyansk loses it, it will still have one more "meteorological" world record: the highest average annual temperature range $\left(61.8^{\circ} \mathrm{C}\right)$, as well as the maximum absolute amplitude $\left(107.1^{\circ} \mathrm{C}\right)$.

On the other hand, Yakutia is considered the planet's treasure. Significant reserves of many minerals which are necessary for the development of industrial production are concentrated here. The Arctic zone includes the continental shelf. The total area of the Russian Arctic territory is about 3 million $\mathrm{km}^{2}$ or $18 \%$ of the entire territory of the country and the share of Yakutia is 1.6 million $\mathrm{km}^{2}$. As before, the Arctic attracts an increased interest of tourists, ecologists, biologists, paleobotanists, geologists in connection with various problems. Only at the present time it is associated with significant reserves of hydrocarbons. According to the experts, the Russian Arctic zone contains about 30\% of the world's undiscovered oil reserves and $15 \%$ of the world's undiscovered gas reserves; there are about 2 billion tons of coal in the coastal zones; in addition, placer deposits of many metals were discovered on the shelf, including gold, platinum, tin, polymetals, minerals containing rare earths, niobium, tantalum, diamonds. Nevertheless, the territory of the Arctic shelf is still poorly studied.

According to the Ministry of Energy of the Russian Federation, by the end of $201990 \%$ (1.7 million $\mathrm{km}^{2}$ ) of the area of the Russian continental shelf has been licensed. It is about a quarter of the total area. To date, 43 licenses for the exploration and production of hydrocarbons have been issued to state-owned companies. Undoubtedly, private companies will also be involved in geological exploration and field development in the near future. The strategy for the development of the Arctic zone, of course, should include a set of environmental measures aimed at the careful conservation of natural resources.

\section{Mineral Resource Base}

The territory of Yakutia has a complex geological structure. The western and southern parts are confined to the eastern end of the Siberian Platform, the sedimentary cover of which is composed of thick layers of carbonate and terrigenous rocks. The ancient formations of the platform's crystal foundation come to the surface in the basin of the Aldan, Olekma and Anabar rivers, forming the Aldan-Stanovoy Shield and the Anabar crystal massif. The Archean rocks composing them are 1.9-3.5 billion years old (the Aldan shield) and 2.4-3.2 billion years old (the Anabar massif). More "young" sedimentary rocks of the platform cover of the Late Proterozoic VendianRiphean and Early Paleozoic age, mainly of carbonate composition, are distributed in the south-west and south-east of Yakutia. Sediments of Mesozoic and Cenozoic age, composed mainly of terrigenous sand-clay material, perform deflections (Vilyuyskaya syneclise, Preverkhoyan deflection). In the basin of the upper course of the Vilyui River, stratified rocks of the main composition (the so-called traps) are widely developed, occupying vast spaces. In the east of the territory is the Verkhoyano-Kolyma Mesozoic folded region. Thick strata of terrigenous Mesozoic sediments form mountain ranges here, among which there are massifs of granitoids and other igneous rocks of Paleozoic and Late Proterozoic age [3]. The state of the mineral resource base of a number of minerals of Yakutia is first covered in the open press in the collection dedicated to the 50th anniversary of the geological survey of the Republic of Sakha (Yakutia) [4].

Yakutia is often called the pantry of the planet, and this is true. There are deposits of many minerals (Figure 1). South Yakutia is, first of all, the largest reserves of coal and iron ores, deposits of gold, platinum, rare earth elements, niobium, tantalum, uranium, apatite ores, precious stones and other minerals. Eastern Yakutia is a polymetallic belt of the republic. In its depths are gold, silver, tin, tungsten, manganese, antimony, mercury, titanium, lead, copper, platinum, rare earths, precious stones, etc. In Western Yakutia, large deposits of oil and gas, zeolites, rock salts, building materials and other minerals have been discovered [5]. A pearl can be called a diamond deposit. In the Yakut diamond-bearing province, more than 1,000 kimberlite pipes are known, among them 150 contain diamonds. The largest of them (Udachnaya, Yubileynaya, Aikhal, Mir, Internatsionalnaya, Botuobinskaya, Nyurbinskaya pipes; placers of the Anabar and Prilensky diamond-bearing areas) annually give millions of carats of diamonds. The province's proven diamond reserves account for $73.5 \%$ of the Russian Federation's reserves [6, 7]. In addition to diamonds, rare precious stones include charoite, chrome diopside and other colored stones [8-10].

A number of deposits of various minerals are considered unique and large in terms of raw material reserves. The Chayandinskoye oil and gas condensate field, located on the territory of Western Yakutia in the Leno-Tunguska oil and gas province, is unique. This province contains all the currently explored and previously estimated reserves of oil and helium, as well as $82 \%$ of the gas reserves of Yakutia, which are listed on the state balance sheet. The Deputatskoye tin deposit and the rich tin-bearing placers associated with it are considered unique. The Tirehtyakh placer has no 
analogues in Russia both in terms of reserves and sand quality. Tin concentrate contains indium, scandium, niobium, and tungsten [11-14].

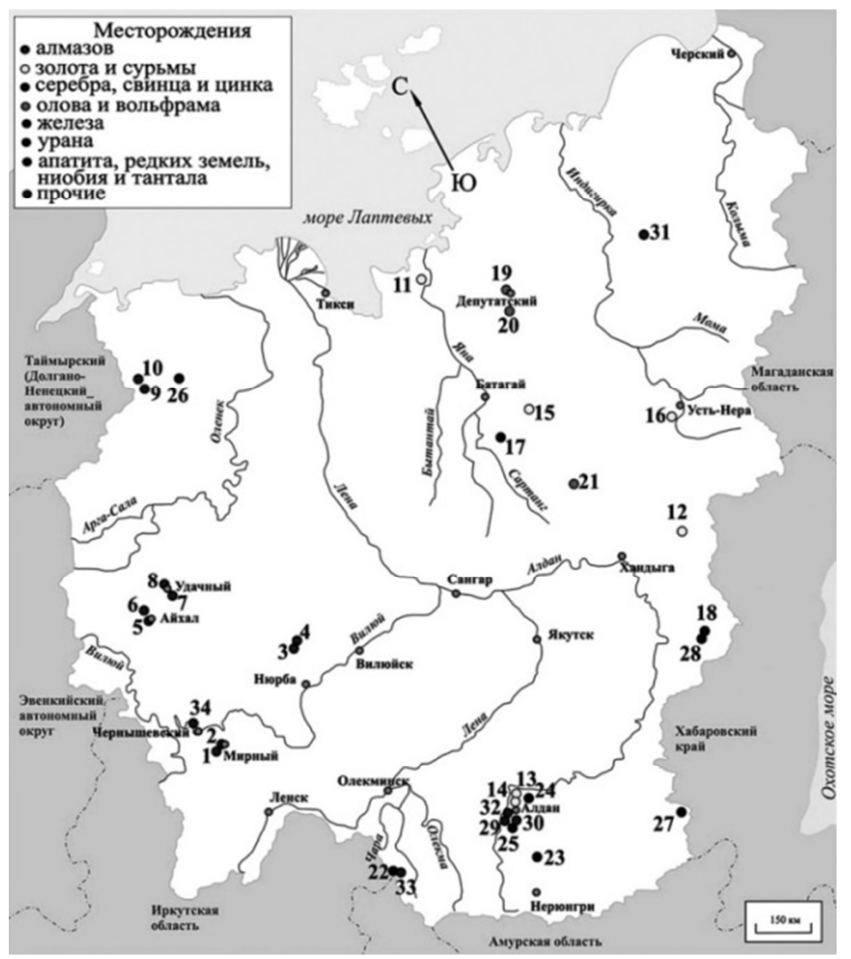

Figure 1. Mineral deposits of Yakutia. Deposits: diamonds: mines: 1. Internatsionalnaya, 2. Mir, 3. Botuobinskaya, 4. Nyurbinskaya, 5. Aikhal, 6. Yubileynaya, 7, Zarnitsa, 8 Udachnaya; placers: 9, Billakh River, Ebelakh River; gold: 10 Ebelakh River, 11 Kuchus, 12 Nezhdaninskoye, 13 Kuranakh group; placers: Bolshoy Kuranakh River; antimony and gold: 14 Bolshoy Kuranakh River, 15 Sentachan, 16 Sarylakh; silver: 17 Forecast; lead and zinc: 18 Sardana; tin: 19 Deputatskoe, 20 Tirekhtyakh Brook; tungsten and copper: 21 Agylkinskoe; iron: 22 Tarynakhskoe, Imalykskoe, Gorkitskoe, 23 Taiga, Desovskoe; uranium and gold: 24 Elkonskaya group; apatite and rare earths: 25 Seligdar; niobium and rare earths: 26 Tomtor; carbonatite massifs with niobium-tantalum-rare earth mineralization: 27 Arbarastakh, 28 Gornozersky; rock crystal: 29 Perekatnoye; amethyst: 30 Deception; agate: 31 Mustach; chrome diopside: 32 Inaglinskoe; charoite: 33 Sirenevy Kamen; collectible minerals (viluit, grossular): 34 Akhtarandinskoe (Skarnovoe).

The gold and antimony deposits of Sarylakh and Sentachan are also large. At present, these are the only deposits in Russia where antimony is extracted. One of the largest and most developed in the Russian Federation is the mineral resource base of gold. The state balance of minerals includes 815 deposits, the reserves of which are $12.3 \%$ of the total Russian reserves. The largest in the republic and the fourth in Russia in terms of gold reserves (more than 632 tons) is the Nezhdaninskoye gold deposit, which is located in the Yano-Indigirskaya gold-bearing province. Recently, in the Verkhnetokinsky district of Southern Yakutia, the Gross deposit with reserves of 265 tons of gold and 1340 tons of silver was explored [15].

Significant reserves and resources of silver are concentrated in the actual silver, complex silver-polymetallic, gold-antimony and other deposits and manifestations. The state balance sheet includes 69 deposits of silver, and the main reserves of this metal are associated with the largest deposit in Yakutia Forecast (4.4 thousand tons), explored in the Yano-Adychansky district.

In terms of the average content of tungsten trioxide, the Agylkinskoye field is not inferior to the best deposits in the world, and in terms of reserves and forecast resources, it can be considered as unique. The ore body with the balance reserves of tungsten was traced to $1220 \mathrm{~m}$, the fall-to 500$860 \mathrm{~m}$. The capacity varies from 2.1 to $8.8 \mathrm{~m}$, the average is $4.3 \mathrm{~m}$. This type of deposit is the main supplier of tungsten concentrates in the global production.

The Tomtorskoye complex rare-metal deposit located beyond the Arctic Circle is also considered one of the largest in the world. Niobium-tantalum and rare-earth ores are concentrated in the weathering crusts of the carbonatites of this deposit. The ores of the so-called tomtor type belong to the genetic type of epigenetically altered, partially redeposited laterite crusts of carbonatite weathering. The thickness of the weathering crust reaches $300 \mathrm{~m}$. The main minerals of the ores are niobium pyrochlore and rare earth phosphates. The content of these minerals in rocks usually does not exceed 1-5\%. In Tomtor rocks (in weathering crusts) they are rock-forming: the content of niobium pyrochlore and rare-earth phosphates ranges from 10 to $80 \%$. In fact, the ores are niobium-a rare earth concentrate.

And on the territory of Southern Yakutia there is the largest mineral resource base of uranium in Russia. In the late 1950s the Elkon uranium ore region was discovered in Aldan shield, where about 40 uranium deposits were discovered [16]. All deposits of the Elkon uranium ore region are represented by stockwork gold-uranium ores in the zones of potassium metasomatites ("metasomatic" type according to the IAEA classification). The uranium content in the ores varies from 0.112 to $0.355 \%$.

The Vilyuisk region of Western Yakutia was the main place of gold and platinum mining before the discovery of the Aldan deposits. Until 1953 prospecting for gold and platinum was allowed here. Until now the region is attractive, as it is well developed and everywhere you can extract gold and platinum by the prospecting method. Placer deposits are complex: in addition to these components, the ores contain minerals containing a number of rare metal elements and diamonds. Unfortunately, the pebbles from these placer deposits are used for "filling" roads.

Many deposits are complex, which should be taken into account when extracting the main useful ore. In Siberia and the Far East, there are several large complex deposits associated with ultrabasic-alkaline carbonatite complexes (Tomtor, Gek, Pivotny, Arbarastakh, etc.) with large reserves of rare and scattered elements - niobium, tantalum, strontium, barium, phosphorus (apatite), rare earth elements, and many others.

The uranium deposits of the Elkon district contain in their composition, in addition to uranium, significant amounts of gold, molybdenum and a number of other elements. The numerous dumps left in place after the development of mineral deposits are essentially secondary deposits with significant reserves of the useful component. For many years, 
the diamond mining company has been working out its own "tailings" of processing plants, thus adding to the total number of extracted diamonds.

The "dumps" of gold mining enterprises, according to the experts, due to the backwardness of our gold recovery technologies, sometimes contain up to $50 \%$ of the initial useful component content, and possibly a number of other equally valuable ones. When using selective methods of ore processing, extraction losses are $25-40 \%$, sometimes reaching $60 \%$. The ore part of the gold reserves in Russia accounts for $85 \%$, and these are all complex ores. For example, in the "dumps" of the Sarylakh gold-antimony deposit, up to tens of grams of gold remain, not counting the antimony concentrate. Of course, with those "hurricane" gold contents in the ores of this deposit, these remnants today seem just "crumbs". It is no secret that many investors export the concentrate for further allocation of a useful component. This happens when developing gold deposits.

It is known that in Russia for 1 billion tons of oil extracted from the subsurface there are almost 3 billion tons of oil left in the subsurface and destroyed due to technologically backward, extensive production methods. Russian scientists have long developed methods for extracting oil from fields that are used abroad. Today Russia ranks first in oil production and second in reserves. Therefore, why go back to the old fields, when you can successfully develop new regions, while receiving billions of dollars in profits? The absence of a deep oil refining system leads to significant economic losses. All this indicates the lack of an effective system of state natural resources management.

Most of the raw materials regions of Siberia under the current economic policy are donors to the federal budget, and some are considered depressed. According to academician D. S. Lvov [17, 18], only $10 \%$ of the deposits belong to the state, and only $52 \%$ of the rent tax (payments for the use of natural resources) go to the central budget, $48 \%$ is the shadow income, which goes largely abroad.

\section{Conclusion}

The contribution of Yakutia to the Russian economy is estimated in trillions of rubles. Precious, non-ferrous and ferrous metals, energy carriers, building materials and other minerals-all this goes to the general piggy bank of the country. Mineral extraction accounts for $46.2 \%$ of the gross regional product of the republic. At the same time, Yakutia ranks 7 th in the country, and in terms of the quality of life of the local population, it ranks $72 \mathrm{nd}$. This is in the most severe region of the country for human life.

If we look into the future and assume that the state of Siberia's resources may be depleted, then the maintenance of this once rich region will become unprofitable. What then expects the population of Siberia and the Far East? It may happen that the country begins to get rid of (or lease out on a concession) separate territories together with the population living there. First of all, for example, China or Japan. Already now the issue of concession for some territories of this gigantic region is being discussed.

Currently the mineral wealth of the Russian Federation is only interested in certain groups (mainly oligarchs) and in fact they are given to them. As for the population, in addition to the "headache" associated with environmental problems that arise during the development of deposits, they do not receive anything in return.

Solving the issue of fair distribution of mineral resources and rent would improve the social sphere of the regions: infrastructure, free quality education, medical care, scientific development and environment. Rent for the use of mineral deposits should become the main source of income for local budgets.

\section{References}

[1] Marshintsev V. K., Gadiyatov V. G. Riches of the Yakut Subsoil. Mineral Reserves, Mineral Resource Base. Voronezh, 2020. 320 p. (In Russ).

[2] Cold poles. https://dic.academic.ru/dic.nsf/ruwiki/1101108 (In Russ).

[3] Geology of the Yakut ASSR. Moscow, 1981. 300 p. (In Russ).

[4] 50 years of the Geological Survey of the Republic of Sakha (Yakutia). Collection. Issue Moscow, 2007. 382 p. (In Russ).

[5] Geology of the USSR. Vol. XVIII. Yakut ASSR. Mineral Resources. Moscow, 1979. 441 p. (In Russ).

[6] Gadiyatov V. G. Semiprecious Stones Formations of the North-East of Asia. Voronezh, 2005. 272 p. (In Russ).

[7] Gadiyatov V. G., Gadiyatova M. V., Goncharova I. I. Commercial Gemology. Voronezh, 2007. 397 p. (In Russ).

[8] Gadiyatov V. G., Marshintsev V. K. Colored Stones of Yakutia and their Deposits. Yekaterinburg, 2000. 328 p. (In Russ).

[9] Marshintsev V. K. Gadiyatov V. G. Semiprecious Stones of Yakutia. Yakutsk, 2015. 88 p. (In Russ).

[10] Kyivlenko E. Y. Geology of Gems. Moscow, 2000. 82 p. (In Russ).

[11] Kovalev L. N. Mineral Resource Potential of the Republic of Sakha (Yakutia).

http://federalbook.ru/files/FS/Yakutiya/Soderjanie/III/Kovalev .pdf (In Russ).

[12] Kovalev L. N., Ivanov G. S., Sitnikov V. S., et al. The State of the Mineral Resource Base of the Republic of Sakha (Yakutia). Scientific and Innovative Support for Optimal Ways of its Development. https://cyberleninka.ru/article/n/sostoyaniemineralno-syrievoy-bazy-respubliki-saha-yakutiya-i-nauchnoinnovatsionnoe-obespechenie-optimalnyh-putey-ee-razvitiya (In Russ).

[13] Flerov B. L. Tin Ore Deposits of the Yano-Kolyma Folded Region. - Novosibirsk, 1976. 283 p. (In Russ).

[14] Pavlovsky A. B. Mineral Resource Base of the World and Russia: State, Development and Prospects. Tin // "Mineral Raw Materials". Geological and Economic Series. No. 27. Moscow, 2008. 96 p. (In Russ). 
[15] Zubkov Y. A., Sagir A. V., Chvarova N. V. "Uguysky" Type of Large-volume Gold Deposits Formed in the Linear Weathering Crust (South-Western Yakutia). // National Geology, No. 2. 2020. Pp. 32-45. (In Russ).

[16] Certificate on the State and Prospects of Using the Mineral Resource Base of the Republic of Sakha (Yakutia) as of 01.01.2017.
https://vsegei.ru/ru/info/gisatlas/dvfo/okrug/Sprav MSB DVF O.doc (In Russ).

[17] Lvov D. S. He Knew How to Revive Russia. http://www.stoletie.ru/sozidateli/on_znal kak_vozrodit_rossij u_133.htm (In Russ).

[18] Lvov D. S. Return the Rent to the People. - Online resource. Finmarket. April 3, 2001. (In Russ). 